\title{
RING MATRIKS ATAS RING KOMUTATIF
}

\author{
Achmad Abdurrazzaq, Ari Wardayani, Suroto \\ razzaq.ganesha@gmail.com \\ Universitas Jenderal Soedirman
}

\begin{abstract}
This paper discusses a matrices over a commutative ring. A matrices over commutative rings is a matrices whose entries are the elements of the commutative ring. We investigates the structure of the set of the matrices over the commutative ring. We obtain that the set of the matrices over the commutative ring equipped with an addition and a multiplication operation of matrices is a ring with a unit element.
\end{abstract}

Keywords : set, matrices, ring, matrices over commutative rings.

ABSTRAK. Makalah ini membahas tentang matriks atas ring komutatif. Matriks atas ring komutatif yaitu matriks dengan entri-entrinya merupakan elemen pada ring komutatif. Selanjutnya, diselidiki struktur yang terbentuk dari himpunan matriks atas ring komutatif tersebut. Hasil yang diperoleh adalah himpunan matriks atas ring komutatif yang dilengkapi operasi penjumlahan dan perkalian matriks merupakan ring dengan elemen satuan

Kata kunci : himpunan, matriks, ring, matriks atas ring komutatif, ring polinomial.

\section{PENDAHULUAN}

Sistem matematika merupakan satu himpunan tak kosong atau lebih yang dilengkapi dengan satu operasi biner atau lebih yang memenuhi sifat-sifat tertentu. Sistem matematika yang terdiri dari satu himpunan tak kosong yang dilengkapi dengan sebuah operasi biner diantaranya yaitu grupoid, semigrup, monoid, dan grup. Adapun sistem matematika yang terdiri dari satu himpunan tak kosong yang dilengkapi dengan dua buah operasi biner diantaranya yaitu ring, daerah integral dan lapangan. Menurut Fraleigh (2002), himpunan bilangan riil dan kompleks yang dilengkapi dengan operasi penjumlahan aritmatika merupakan sistem matematika grup. Selanjutnya, jika himpunan bilangan riil dan kompleks dilengkapi operasi penjumlahan dan perkalian aritmatika maka himpunan bilangan riil dan kompleks tersebut merupakan suatu ring. 
Matriks merupakan susunan elemen yang berbentuk persegi panjang yang disusun menurut baris dan kolom. Matriks merupakan salah satu kajian pada bidang aljabar yang memiliki operasi yang berbeda dari operasi aritmatika. Pembahasan mengenai matriks dengan entri-entrinya merupakan elemen himpunan bilangan riil dan kompleks telah dibahas oleh Anton (2010). Matriks yang dibahas oleh Anton merupakan suatu matriks atas ring riil atau ring kompleks. Sukartini (2003) mengkaji mengenai kongruensi matriks hermite atas ring polinomial. Pada penelitian tersebut matriks yang dibahas adalah matriks yang entri-entrinya merupakan elemen pada ring polinomial. Ring polinomial merupakan salah satu bentuk khusus dari ring.

Penelitian ini membahas mengenai pembentukan matriks dengan memperumum entri-entrinya yaitu elemen pada ring komutatif. Selanjutnya, dengan membentuk matriks atas ring komutatif ini maka secara otomatis struktur beserta sifat-sifat matriks yang dibahas pada Anton dan matriks yang dikaji oleh Sukartini termuat di dalam matriks atas ring komutatif ini.

\section{METODE PENELITIAN}

Metode yang digunakan dalam penelitian ini adalah studi pustaka dengan cara mengkaji buku-buku teks yang berkaitan dengan pembentukan ring matriks atas ring komutatif. Adapun langkah-langkah yang dilakukan dalam penelitian ini yaitu :

(1) Mendefinisikan matriks dengan memperumum entri-entrinya yang merupakan elemen pada ring komutatif.

(2) Mendefinisikan himpunan matriks atas ring komutatif serta operasi pada himpunan tersebut.

(3) Membuktikan struktur yang terbentuk dari sistem matematika himpunan matriks atas ring komutatif merupakan ring. 


\section{HASIL DAN PEMBAHASAN}

Pada hasil dan pembahasan ini dibahas mengenai pembentukan matriks atas ring komutatif dan selanjutnya akan ditunjukkan sistem matematika ring yang terbentuk dari matriks atas ring komutatif dan ring polinomial atas ring tersebut.

\subsection{Matriks Atas Ring Komutatif}

Misalkan $R$ merupakan ring komutatif dengan elemen nolnya adalah $e_{0}$. Apabila $R$ merupakan ring komutatif dengan elemen satuan maka elemen satuannya dinotasikan $e_{1}$. Selanjutnya, pembahasan pada sub bab ini diawali dengan mendefinisikan suatu matriks dengan entri-entrinya merupakan elemen pada ring komutatif.

Definisi 1 Misalkan $R$ adalah ring komutatif. Matriks berukuran $m \times n$ disebut matriks atas ring komutatif $R$ jika setiap entri matriks adalah elemen pada $R$.

Karena $R$ dan $C$ masing-masing merupakan ring komutatif maka matriks yang entri-entrinya elemen pada $R$ dan $C$ seperti pada pembahasan Anton (2010) merupakan bentuk khusus dari matriks atas ring komutatif dengan entri-entrinya elemen pada ring komutatif. Matriks yang dibahas oleh Anton untuk selanjutnya disebut matriks biasa. Berikut ini diberikan definisi himpunan matriks atas ring komutatif menurut Brown (1993:10).

Definisi 2 Misalkan $R$ adalah ring komutatif, maka himpunan semua matriks berukuran $m \times n$ atas $R$, dinotasikan $M_{m \times n}(R)$ disebut himpunan matriks atas ring komutatif $R$.

Berdasarkan Definisi 2, diperoleh bahwa bentuk umum dari $M_{m \times n}(R)$ adalah

$$
M_{m \times n}(R)=\left\{\left[a_{i j}\right] \mid a_{i j} \in R, \forall i=1,2, \ldots, m, j=1,2, \ldots, n\right\} .
$$


Pada penelitian ini matriks yang digunakan merupakan matriks persegi, sehingga himpunan matriksnya adalah $M_{n \times n}(R)$.

Operasi penjumlahan dan perkalian matriks terdefinisi dengan baik di $M_{n \times n}(R)$. Ambil sembarang $A, B, C, D \in M_{n \times n}(R)$ dengan $A=C$ dan $B=D$ dimana $A=\left[a_{i j}\right], B=\left[b_{i j}\right], C=\left[c_{i j}\right], D=\left[d_{i j}\right]$, untuk setiap $a_{i j}, b_{i j}, c_{i j}, d_{i j} \in R$ dan $i, j=1,2, \ldots, n$. Karena $A=C$ dan $B=D$ maka $a_{i j}=c_{i j}$ dan $b_{i j}=d_{i j}$ untuk setiap $i, j=1,2, \ldots, n$. Dengan demikian berlaku

$$
\begin{gathered}
A+B=\left[a_{i j}\right]+\left[b_{i j}\right]=\left[a_{i j}+b_{i j}\right]=\left[c_{i j}+d_{i j}\right]=\left[c_{i j}\right]+\left[d_{i j}\right]=C+D \\
A \times B=\left[\sum_{q=1}^{n} a_{i q} b_{q j}\right]=\left[\sum_{q=1}^{n} c_{i q} d_{q j}\right]=C \times D .
\end{gathered}
$$

Hal ini berarti operasi penjumlahan dan perkalian matriks terdefinisi dengan baik di $M_{n \times n}(R)$. Pada suatu matriks, yang mempengaruhi bentuk dan sifat yang menyertainya adalah entri-entri yang membentuk matriks tersebut.

\subsection{Struktur pada Matriks Atas Ring Komutatif}

Setelah membentuk matriks atas ring komutatif, selanjutnya ditunjukkan mengenai sistem matematika ring yang terbentuk dari himpunan matriks atas ring komutatif. Sistem matematika yang dibahas merupakan sistem matematika yang terdiri dari himpunan matriks atas ring komutatif yang disertai dengan dua buah operasi, yaitu operasi penjumlahan dan perkalian matriks. Karena matriks atas ring komutatif merupakan perumuman dari matriks biasa, maka struktur yang terbentuk dari matriks atas ring komutatif juga memperumum struktur dari matriks biasa.

Berikut ini diberikan lemma untuk himpunan matriks atas ring komutatif yang disertai operasi penjumlahan matriks.

\section{Lemma 3}

Himpunan matriks $M_{n \times n}(R)$ yang dilengkapi dengan operasi penjumlahan matriks merupakan grup Abel. 
Bukti. Berikut ini akan ditunjukkan bahwa himpunan matriks atas ring komutatif yang disertai operasi penjumlahan matriks merupakan grup Abel.

a. Misalkan $A, B \in M_{n \times n}(R)$ dengan $A=\left[a_{i j}\right]$ dan $B=\left[b_{i j}\right]$, untuk setiap $a_{i j}, b_{i j} \in R$ dan $i, j=1,2, \ldots, n$. Hasil penjumlahan dari matriks $A$ dan $B$ adalah $A+B=\left[a_{i j}\right]+\left[b_{i j}\right]=\left[a_{i j}+b_{i j}\right]$, untuk $i, j=1,2, \ldots, n$. Karena $a_{i j}, b_{i j} \in R$ maka berlaku $a_{i j}+b_{i j} \in R$, sehingga diperoleh bahwa $A+B \in M_{n \times n}(R)$.

b. Sifat assosiatif penjumlahan terpenuhi di $M_{n \times n}(R)$, karena untuk setiap $A, B, C \in M_{n \times n}(R)$ dengan $A=\left[a_{i j}\right], B=\left[b_{i j}\right]$, dan $C=\left[c_{i j}\right]$, untuk setiap $a_{i j}, b_{i j}, c_{i j} \in R$ dan $i, j=1,2, \ldots, n$, berlaku $(A+B)+C=\left(\left[a_{i j}\right]+\left[b_{i j}\right]\right)+\left[c_{i j}\right]=$ $\left[a_{i j}\right]+\left(\left[b_{i j}\right]+\left[c_{i j}\right]\right)=A+(B+C)$.

c. Terdapat matriks nol $E=\left[d_{i j}\right] \in M_{n \times n}(R)$ dengan $d_{i j}=e_{0}$ untuk setiap $i, j=1,2, \ldots, n$, sedemikian sehingga untuk setiap $A \in M_{n \times n}(R)$ berlaku $A+E=E+A=A$. Hal ini dapat ditunjukkan oleh $A+E=\left[a_{i j}\right]+\left[d_{i j}\right]$ $=\left[d_{i j}\right]+\left[a_{i j}\right]=\left[a_{i j}\right]$. Jadi $E$ merupakan elemen nol pada $M_{n \times n}(R)$.

d. Untuk setiap $A=\left[a_{i j}\right] \in M_{n \times n}(R)$ dengan $a_{i j} \in R$ dan $i, j=1,2, \ldots, n$, terdapat $A^{-1}=-A=\left[-a_{i j}\right] \in M_{n \times n}(R)$ untuk setiap $-a_{i j} \in R$ yang merupakan invers dari $a_{i j}$ terhadap operasi penjumlahan pada ring komutatif $R$, sehingga berlaku $A+A^{-1}=\left[a_{i j}\right]+\left[a_{i j}^{-1}\right]=\left[a_{i j}\right]+\left[-a_{i j}\right]=\left[a_{i j}+\left(-a_{i j}\right)\right]=\left[d_{i j}\right]=E$ dan $A^{-1}+A=\left[a_{i j}^{-1}\right]+\left[a_{i j}\right]=\left[-a_{i j}\right]+\left[a_{i j}\right]=\left[\left(-a_{i j}\right)+a_{i j}\right]=\left[d_{i j}\right]=E$. Jadi terbukti bahwa $A^{-1}=-A$ merupakan invers matriks $A$ terhadap operasi penjumlahan di $M_{n \times n}(R)$. 
e. Sifat komutatif penjumlahan terpenuhi di $M_{n \times n}(R)$, karena untuk setiap

$$
\begin{aligned}
& A, B \in M_{n \times n}(R) \quad \text { dengan } A=\left[a_{i j}\right] \quad \text { dan } B=\left[b_{i j}\right], \quad \text { berlaku } \\
& A+B=\left[a_{i j}\right]+\left[b_{i j}\right]=\left[a_{i j}+b_{i j}\right]=\left[b_{i j}+a_{i j}\right]=\left[a_{i j}\right]+\left[b_{i j}\right]=B+A .
\end{aligned}
$$

Karena semua aksioma pada grup dan sifat komutatif terpenuhi maka terbukti $\left(M_{n \times n}(R),+\right)$ merupakan grup Abel.

Himpunan matriks atas ring komutatif yang dilengkapi dengan operasi perkalian matriks membentuk sistem matematika seperti dijelaskan pada lemma berikut.

\section{Lemma 4}

Himpunan matriks $M_{n \times n}(R)$ yang dilengkapi dengan operasi perkalian matriks merupakan semigrup.

Bukti. Berikut ini ditunjukkan bahwa himpunan matriks atas ring komutatif yang disertai dengan operasi perkalian matriks merupakan semigrup.

Untuk setiap $A, B, C \in M_{n \times n}(R)$ dengan $A=\left[a_{i j}\right], B=\left[b_{i j}\right], \quad$ dan $C=\left[c_{i j}\right]$, dimana $a_{i j}, b_{i j}, c_{i j} \in R$ dan $i, j=1,2, \ldots, n$, berlaku

a. Hasil perkalian dari matriks $A$ dan $B$ adalah $A \times B=\left[c_{i j}\right]$, dengan $c_{i j}=\sum_{q=1}^{n} a_{i q} b_{q j} \quad$ untuk $i, j=1,2, \ldots, n$. Karena $a_{i q}, b_{q j} \in R \quad$ maka $\sum_{q=1}^{n} a_{i q} b_{q j} \in R$ sehingga diperoleh bahwa $A \times B \in M_{n \times n}(R)$.

b. Sifat assosiatif perkalian yaitu

$$
(A \times B) \times C=\left[\sum_{q=1}^{n} a_{i q} b_{q j}\right] \times\left[c_{i j}\right]=\left[a_{i j}\right] \times\left[\sum_{r=1}^{n} b_{q r} c_{r j}\right]=\left[a_{i j}\right] \times\left(\left[b_{i j}\right] \times\left[c_{i j}\right]\right) .
$$

Karena setiap aksioma pada semigrup terpenuhi maka terbukti $\left(M_{n \times n}(R), \times\right)$ merupakan semigrup. 
Selanjutnya diberikan lemma yang menyatakan bahwa operasi perkalian matriks bersifat distributif terhadap penjumlahan pada $M_{n \times n}(R)$.

\section{Lemma 5}

Untuk setiap $A, B, C \in M_{n \times n}(R)$ berlaku, $A \times(B+C)=A \times B+A \times C \quad$ dan $(B+C) \times A=B \times A+C \times A$.

Bukti. Ambil sembarang $A, B, C \in M_{n \times n}(R)$ dengan $A=\left[a_{i j}\right], B=\left[b_{i j}\right]$, dan $C=\left[C_{i j}\right]$, untuk setiap $a_{i j}, b_{i j}, c_{i j} \in R$ dengan $i, j=1,2, \ldots, n$. Selanjutnya perhatikan bahwa

$$
\begin{aligned}
& A \times(B+C)=\left[\sum_{q=1}^{n}\left(a_{i q} b_{q j}+a_{i q} c_{q j}\right)\right]=\left[\sum_{q=1}^{n} a_{i q} b_{q j}+\sum_{q=1}^{n} a_{i q} c_{q j}\right]=(A \times B)+(A \times C) \text { dan } \\
& (B+C) \times A=\left[\sum_{q=1}^{n}\left(b_{i q} a_{q j}+c_{i q} a_{q j}\right)\right]=\left[\sum_{q=1}^{n} b_{i q} a_{q j}+\sum_{q=1}^{n} c_{i q} a_{q j}\right]=(B \times A)+(C \times A) . \text { Jadi }
\end{aligned}
$$

terbukti bahwa sifat distributif operasi perkalian terhadap penjumlahan berlaku di $M_{n \times n}(R)$

Berdasarkan uraian lemma 3, lemma 4, dan lemma 5 diperoleh sistem matematika yang terdiri dari satu himpunan yang dilengkapi dengan dua buah operasi biner.

\section{Teorema 6}

Himpunan matriks $M_{n \times n}(R)$ yang dilengkapi dengan operasi penjumlahan dan perkalian matriks merupakan ring.

Bukti. Berdasarkan lemma 3 diperoleh bahwa $\left(M_{n \times n}(R),+\right)$ merupakan grup Abel, dan menurut lemma 4, sistem matematika $\left(M_{n \times n}(R), \times\right)$ merupakan semigrup. Selanjutnya, menurut lemma 5 diperoleh bahwa sifat distributif 
perkalian terhadap penjumlahan berlaku di $M_{n \times n}(R)$. Hal ini menunjukkan bahwa $\left(M_{n \times n}(R),+, \times\right)$ merupakan ring.

Menurut Teorema 6 matriks atas ring komutatif yang dilengkapi operasi penjumlahan dan perkalian matriks merupakan ring dengan elemen satuan. Karena operasi perkalian matriks tidak bersifat komutatif, maka $\left(M_{n \times n}(R),+, \times\right)$ bukan ring komutatif. Hal ini berarti sistem matematika $\left(M_{n \times n}(R),+, \times\right)$ bukan lapangan maupun daerah integral.

\section{KESIMPULAN DAN SARAN}

Matriks atas ring komutatif adalah matriks yang entri-entrinya merupakan elemen dari ring komutatif. Himpunan matriks atas ring komutatif yang dilengkapi dengan operasi penjumlahan dan perkalian matriks merupakan ring dengan elemen satuan, tetapi bukan merupakan lapangan ataupun daerah integral. Untuk selanjutnya penelitian ini dapat dilakukan untuk ideal pada ring matriks atas ring komutatif. Selain itu dapat juga dilakukan pengkajian matriks dengan mengubah entri dari matriks dengan lapangan ataupun daerah integral.

\section{DAFTAR PUSTAKA}

Anton, H. (2010). Dasar-Dasar Aljabar Linier, Jilid 1. Ciputat Tangerang: Binarupa Aksara Publisher.

Brown, W C. (1993). Matrices Over Commutative Rings. New York: Marcell Dekker Inc.

Fraleigh, J.B., \& Katz, V.J. (2002). A First Course in Abstract Algebra, $7^{\text {th }}$ Edition. New York: Addison-Wesley Publishing Company.

Sukartini. (2003). Menentukan Kongruensi Matriks Hermite Atas Ring Polinomial Skripsi S1 pada ITS Surabaya. 